\title{
CHAPTER TWELVE
}

The 'Third Way' and the Governance of the Social in Britain

\author{
Jérôme Tournadre-Plancq
}

Regardless of the 'world of Welfare' in which it functions - to use the term coined by Gøsta Esping-Andersen (Esping-Andersen 1990) - the State has, during a large part of the twentieth century, come to play an essential role in the handling of welfare in liberal democracies. This does not mean that its role amounts to exercising a monopoly. Providing a counterweight to the market in the social-democratic 'compromise', the Welfare State often emerges, in the political reflection of the majority of the post-war centre-left, as the most reliable guarantor for the common good. The Social (Donzelot 1984) is then considered as the best way to reinforce this idea. The 'welfare backlash' (Merrien 2005, 253) which marked the 1980s and 1990s has reversed this belief. Sustaining and feeding on the premise of a 'crisis' of the Fordist Welfare State, this backlash constituted, above all, an ideological attack on an institution accused of 'inefficiency' for which there was only one possible solution: retrenchment. Particularly widespread in Great Britain during the Thatcher years, this offensive takes as its model the ideal of the 'Hollow State' (Peters 1993). It is given substance in various movements running concurrently: a wave of privatisations affecting certain public services, liberalisation leading to the fragmentation of welfare between several bodies (private and 'para-public') deregulation of the Social through the emergence of internal markets in some public services and the abandoning of universalism in favour of a better targeted, residual social assistance. Nevertheless, as Colin Crouch (Crouch 2004, 103) remarks, the free market economy thus promoted by neo-Liberalism does not exist in the state of nature. The 
apparent withdrawal of the British Welfare State is only made possible by strengthening the power of a centralised State in order to guarantee the best framework for privatisation and the commodification of welfare (see Gamble 1988).

Whatever form it might take, the questioning of the State's primacy has led to a 'change of style' in the handling of the Social, evident even within the left. Traces of this change can be found more precisely in the theorisation of the Third Way, a political project elaborated at the heart of intellectual and political 'left-wing' groups in the early nineties. Dissatisfied with the traditional ways of apprehending the relationship between public and private initiatives, a number of advocates of this 'new progressivism' (see Gamble and Wright 2004, 1-10) have set out to redefine the new shape of welfare, a step which should lead to a conception of the role of the institution as no longer exclusively that of a 'proprietor or an employer'. The State must, above all, assert itself as a 'partner, an enabler, a catalyst, a coordinator' (Brown 1995, 4). Its principal role (enabling each individual to have access to the resources necessary for his personal development) thus amounts to directly ensuring distribution of its goods and services.

The stance adopted by Thirdwayers as regards the duties of the State can be read as an indictment of the 'interventionism' associated with Old Labour and of a vision of the State the 'nanny State' - mainly influenced by mid-century Fabianism. Douglas Jays' now famous words 'The men of Whitehall know best' best sum up the interventionist, dirigiste attitude of which Old Labour is accused. According to the Third Way, it is essential to allow agents other than the State to participate in the domain of welfare and to ensure the distribution of certain goods and services. Thirdwayers thus hope to pave the way for 'social governance' by proposing the development of partnerships in social protection. This will to reconfigure the domain of welfare has found expression within the framework of a 'New 
Localism, ${ }^{1}$ where different characters in the universe of the Third Way rub shoulders: the community, mutualism and also that ideal local leader — the social entrepreneur.

Finally, it is essential to emphasise that this discussion will focus only on the ideas put forward to legitimise this form of 'governance' and the way these ideas have been circulated in the politico-intellectual debate surrounding the Third Way ${ }^{2}$.

\section{The return of the community}

One of the characteristics of the 'space of theorisation' of the Third Way has been to encourage, within its midst, a confrontation between various currents of thought, going from 'Christian socialism' to 'left-wing liberalism' or, then again, 'Keynesian social democracy.' Despite this pluralism, the main theoreticians of the Third Way have identified two major traits allowing a definition of the social order: the emergence of a new form of individualism ${ }^{3}$ and the growing interdependence of individuals. The tensions which arise from the interaction of these two phenomena can be overcome, according to a majority of Thirdwayers, by emphasising the 'virtues' of the community. The central position occupied by the community in the theoretical corpus of the Third Way can be explained in several ways. One of the first reasons might be the influence on the British centre-left of United States political doctrine

1 ' $[\ldots]$ a strategy aimed at devolving power and resources away from central control and towards front-line managers, local democratic structures and local consumers and communities, within an agreed framework of national minimum standards [...]'. (Stoker 2004, 117)

2 A definition should be given here of what is intended by the Third Way in these pages. Convinced that any domination in a debate is the result of a hegemony in the British market of ideas, in the early 1990s the 'modernising' wing of Labour undertook to mobilise various thinkers (academics, think tanks, experts, etc.) in the elaboration of a 'new' doctrine. This call for intellectual mobilisation has contributed to the emergence of a specific social space: the space of theorisation of the Third Way. Built on a fabric of formal and informal relationships, areas of research and all manner of social exchanges, the space of theorisation has as its sole purpose the elaboration of a 'new progressivism'. The 'Third Way' referred to here is, therefore, not a mere reference to neo-Labour, that is to say to the policies, beliefs and practices of the 'modernisers' but an amalgam of the different contributions made within the space aforementioned, acknowledged by its participants as well as those outside. It can be likened to a sort of maximal agenda from which can be lifted certain theoretical elements necessary for the foundation of 'New Labour'.

3 According to Anthony Giddens, 'New Individualism does not signal a process of moral decay. Rather to the contrary, surveys show that younger generations today are sensitized to a greater range of moral concerns than previous generations. They do not, however, relate these values to tradition, or accept traditional forms of authority as legislating on questions of lifestyle. Some such moral values are clearly post-materialist in Ingelhart's sense, concerning for example ecological values, human rights or sexual freedom'. (Giddens, 1998) 
concerning the community. This philosophy, pivotal to the speeches of the New Democrats of Bill Clinton and $\mathrm{Al}$ Gore, has received the attention of influential members of the space of theorisation, especially that of the think tank Demos, co-founded by Geoff Mulgan, one of Tony Blair's principal advisors. Another reason could be the taking into consideration of the power struggle characterising the Labour party during the nineteen eighties. Faced with a powerful neo-Marxist or Bennite 'left,' presented as the main culprit for Labour's fall from favour, the 'right' and 'centre' of the partisan organisation elaborated a philosophical project likely to change the way the party was perceived in the political arena (Foote 1997). Academics and some members of the party leadership, well-versed in intellectual debate, set out to rediscover the Idealistic, Christian and Liberal roots of the Labour movement. This produced a discourse dominated by notions of 'individual responsibility,' 'civic commitment', and, above all, ‘community' which rapidly became a source of inspiration for Neil Kinnock and the 'modernisers.' Finally, the notion of 'community' took clear shape in the political rivalry of the nineteen nineties. In opposition to an insubstantial vision of the market, accused of favouring the rise of social fragmentation, the notion of community has provided the mainstay for the leftist value of solidarity while at the same time reassuring Conservative voters attached to a cohesive social order. Coveted across the political board, both sides eager to appropriate the idea, 'community' has slowly emerged as the 'new territorialisation of political thought' (Rose 1999, 475).

The recourse to the discourse of community by the Labour 'modernisers' is somewhat ambiguous. If the community can be defined as a social space within which the individual is encouraged to develop, this approach does not inform us completely about where the limits of this concept lie. The various advocates of the Third Way have thus attributed to it in turn a national, local or international dimension. It has become an amalgam of Great Britain, the family, the neighbourhood, ethnic and social associations and civil society. This confusion 
comes from the fact that, more than a 'structure' within which individuals evolve, for the Third Way the community represents a way of perceiving the individual in his environment. It claims the existence of both a social and moral interdependence between people which can operate in the different spheres already mentioned and which should give rise to the good society embodied by the 'cohesive society.' Consequently, the community is supposed to demolish the stance adopted by the neo-Liberal wing of the Conservative party, summed up by the famous words, uttered by Margaret Thatcher in 1987: 'There is no such thing as society.' It provides a timely opposition to market individualism in a British society characterised by the fear of social disintegration.

Whereas Thatcherite neo-Liberalism had turned the market into an ideal 'partner', the Third Way - or at least part of it - aims to involve the community in the responsibility for the Social thus bestowing on it the characteristics of the civil society. For Thirdwayers, civil society emerges as the long-lost child of the politics of the second half of the twentieth century, ignored by a left too busy reinforcing the power of the State in its relationship to the individual and by a right striving, for its part, to give greater importance to the latter. Long neglected, the civil society referred to by the Thirdwayers brings together all those elements which fall outside the remit of the State or the market. Some Thirdwayers envisage it as a flourishing of local communities, attracting in their orbit different associations and organisations. Civil society sometimes emerges as an idyllic space. Ian Hargreaves describes it as 'a place where citizens freely act together to consolidate and express their freedoms, to solve problems, to provide services to each other or simply enjoy each other's company'(Hargreaves 1999).

The Thirdwayers maintain that, after two decades of market assaults and a weakened local democracy due to Conservative policies, civil society, long disdained by a left, partisan of State control, is in dire need of 'renewal.' It must assert itself in order to protect the 
individual from a State judged over-powerful and from a potentially disintegrating market. Given that civil society is not the state of natural harmony the Tories believed it to be, its regeneration might imply government intervention. The public authorities would then be encouraged to organise the mobilisation of the members of the civil society for the common good. Therefore, it is once again thanks to the civic argument that the Third Way seeks to assert its difference. Traces of this Republican stance can be found in the principle of 'community involvement', for example, which influences the granting of government funds to local programmes set up to fight social exclusion.

Some Thirdwayers are now starting to look for the best tools which will enable them to lay down the civic foundations for the civil society. Charles Leadbeater thus suggests that the club could serve as a model for the institutions which the State must encourage to exist at the heart of the civil society (Leadbeater 1997). Such a structure would engender a strong feeling of belonging as well as having the merit of combining 'citizenship' and 'modernity.' Indeed, it reconciles a sense of reciprocity with individual choice. The ambitions of the Third Way as expressed here by one of its 'experts', cannot be more explicit. They consist in encouraging autonomous individuals to participate actively (whatever form that might take), a consequence of which will be the production of social capital. Thus reconfigured, the civil society is transformed into a 'strong civic society' (Blair 2001), within which every individual, by virtue of common shared values, can express a 'civic patriotism' (Brown 2000)' The State must acknowledge this emerging 'reality' by delegating a substantial part of its power and its prerogatives in the domain of welfare. It is partly on this standardised vision of society that rests the theory of 'new mutualism,' the logical outcome of a collective exercise in active citizenship.

\section{The emergence of a 'new mutualism'}


In 1995 Geoff Mulgan and Charles Landry took the defence of a rather curious thesis (Mulgan and Landry 1995). By reading too much Adam Smith without trying to understand him, the Thatcherites and their adversaries seemed to have forgotten the existence of 'another invisible hand', other than the one striving to achieve economic prosperity through market mechanisms. A force for 'generosity, assistance and moral commitment,' such an entity could incite individuals to gather around a common project (Mulgan and Landry 1995, 2). In a society where government control had 'run out of steam' and the market had become 'devalued,' the future of a 'modern' left depends inevitably on an understanding of the mechanisms of this 'other invisible hand,' according to Mulgan and Landry. These two political thinkers suggest that one of these mechanisms is a reassertion of the value of mutualism.

As from the late 1980s, mutualism has become a recurring theme in the debates of the British left and the subject of much theoretical investment within the space of theorisation (Hargreaves 1999), eventually giving rise to a discourse proposing the rehabilitation of 'cooperative socialism' or even 'Socialism without the State.' Consequently, what is paradoxical is the fact that the 'modernity' which 'New Mutualism' purports to embody finds its legitimacy in the continuous references to the history of the working-class movement. The type of socialism represented here is thus a 'grass-root' socialism, anchored in civil society and steeped in moral values, almost legitimist insofar as it is imbued with what are presented implicitly as the 'eternal values of the left.' In 1994, certain 'modernisers' evoked pre-war socialism thus:

Long before the age of post-war State planning, and even Clause 1V, British Socialists were probably acclaimed for their identification with the principles of communitarian fraternity, mutual co-operation, individual responsibility and self-help. Co-operative, friendly societies and trade unions all formed an 
increasingly successful welfare network dedicated to the provision of $[\ldots]$ efficient $[\ldots]$ health and welfare services for their members. (Pollard, Liddle, Thompson 1994, 1)

Although the picture painted here is a somewhat idealistic one, it refers to proven facts. Indeed, the historian Edward P. Thompson has evoked the importance of 'mutual assistance groups' in the constitution of the British working-class movement (Thompson 1963). These corporatist associations - the friendly societies and self-help groups — brought together more than six and a half million individuals at the beginning of the 20th century. Combining religion, politics, social issues, Methodism, Chartism and Owenism, they provided a burgeoning working class with the means to achieve 'collective independence' as early as the 18th century by mutualising the risks linked to illness and unemployment. The autonomous social system set up by these mutualist organisations was, however, marginalized subsequent to the social assistance offered by the State in the National Insurance Act voted in 1911 and then by the setting up of the Welfare State in the 1940s. The 'cooperative socialism' they embodied was then slowly replaced by a more State-controlled progressivism. Yet, it is to the former that Tony Blair, amongst others, referred to at length as early as 1994 :

\footnotetext{
The history of worker's cooperatives, the friendly societies and the unions from which the Labour Party sprang is one of individuals coming together for self-improvement and to improve people's potential through collective action. We need to recreate for the twenty-first century the civil society to which these movements gave birth. (Blair 1994)
}

The allusion to this 'forgotten patrimony' signals the outcome of a period of rehabilitation begun at the end of the nineteen eighties. Individuals caught up in the 'modernising' current set out to evoke the importance of the cooperative and mutualist movement in the Labour constitution at a time when the Labour party was completing its policy review. Frank Field, the minister for Welfare Reform after May 1997, has emerged as 
the pioneer of this rehabilitation process. Aware of his marginality within the Labour party due to his opposition to a certain partisan orthodoxy, Frank Field has participated actively in public debate thanks to his numerous contributions to the mainstream press. True to his reputation as a 'freethinker,' he has rebuked a Labour party which he believes has lost sight of its roots. He has thus enjoined the partisan organisation to stand up for the values of cooperation and to renounce an inclination towards State control, a tendency discredited and undermined, in his opinion, by the standard-bearers of neo-liberalism. The works subsequently published by the Parliamentarian herald much of the social discourse of neoLabour's first mandate, referring explicitly to the experiment of friendly societies and mutualism. Taking advantage of his presence in different social worlds (think tanks, press, etc.), Field has been one of the principal agents of reconversion within the space of theorisation as regards this aspect of the history of British socialism.

David Green, a character as unorthodox as Field can be but not part of the 'modernising' current, has also had a role to play in this process of rehabilitation. A former Labour councillor, strongly influenced by ethical socialism, Green is nonetheless a member of the Institute of Economic Affairs (IEA) a neo-Liberal think-tank of which he chairs the Health and Welfare Unit. Since the early nineteen eighties, he has also written several essays on the subject of working-class mutualism and its possible applications in today's society. ${ }^{4}$. His work has been widely circulated thanks to the strong influence of the IEA on the media. Moreover, it can be added that David Green has in a certain way contributed to strengthening Frank Field's position and therefore his ideas in the space of theorisation by allowing him, on numerous occasions, to express himself and publish his work in the framework of the IEA.

The ideas put forward by Field and Green, increasingly evident in the market of ideas as New Labour has come closer to power, fall into the same mould: they criticise a 'Statist left.'

4 Green is the author of Mutual Aid or Welfare State (1984), Working Class Patients and the Medical Establishment : Self-Help from the Mid-Nineteenth Century to 1948 (1985) and Reinventing Civil Society (1993). 
Yet the two men diverge when it comes to their respective ambitions. The former wants to allow the modernisers to make a definitive break from Old Labour whereas the latter aims to prove, without resorting to the neo-Liberal phraseology which little by little fell from favour during the 1990s, that the Labour movement has become a 'bureaucratic' ideology. Despite the relatively marginal positions occupied by their authors in their respective political camps, the broad reception given to Field and Green's ideas by the political world is an indication of the strong rise, both on the left and on the right, of the feeling that it has become electorally unviable to build a political project taking as the sole point of reference either the State or the market. On the left, this feeling is quite clearly at the heart of the reflection elaborated by certain elements of the 'modernising' current. As well as the return to favour of a 'socialism without the State,' its existence could be perceived as early as the second half of the 1980s when, following the popular 'success' of Thatcher's privatisations, the Labour party felt constrained to opt for the notion of Social Ownership over State Ownership. The 'new ideal' of the left-wing party thus became:

\footnotetext{
... an economy in which enterprises are owned and managed by their employees - or, where appropriate, by consumers or local communities - and thereby serve the wider interests of their consumers and the community. (Shaw 1994, 87)
}

These reorientations in Labour doctrine manifest the will to disengage the State which can be justified in 'progressive' terms. Furthermore, these changes rest on values dear to 'new social democracy:' a sense of duty towards the community, civic commitment, etc. In concrete terms, this 'redefinition of the frontiers between the State and individual responsibility' (Field, 1997) favours the development of the third sector, a space belonging neither to the public nor the private sectors. Gathering mainly mutualist groups, corporatist or voluntary associations as well as other non-profit making organisations, the third sector 
emerges as the successor of the working-class cooperative movement. Thanks to the values it claims to represent, this sector offers a practical application of the discourse on community; it seems to crystallise social interdependence while at the same time preserving the individual's desire for autonomy. Thus, Frank Field, in a document published in 1996, proposes the setting up of a stakeholder welfare, built on what might be the 'emerging values' of contemporary British society: property and control (Field 1996). The 'voters,' demanding that their 'growing social autonomy' be acknowledged, now wish to benefit from personalised social benefit, according to Frank Field. In order to do so, they can resort to free association. The government must, therefore, provide them with the means to set up their own institutions for social protection outside the influence of the State.

The renewed interest in mutualism does not end with a reappraisal of the long forgotten roots of the Labour movement. It can also be interpreted as a questioning of a trade union movement judged incapable of meeting the new expectations of the workers. The diversification and unpredictability of the working experience, the spread of self-employment, the growing flexibility of the workplace and the more personal relationships which now exist between employer and employee are all arguments put forward by a majority of Thirdwayers to denounce the ineffectuality of the 'traditional' trade union structures. Particularly widespread in the industrial and public sectors, trade unions seem to be less popular with younger workers and with those employed in highly flexible professional fields such as the tertiary sector or small companies. Researchers from Demos have outlined a new structure, based on the principles of mutualism, able to appeal to millions of salaried workers: the employee mutual. The employee mutual is a local structure aiming to help people 'find work, improve their qualifications and organise their professional life' (Leadbeater and Martin 1999, 9). It caters for both salaried workers and the unemployed. Claiming to offer a framework for the individual to participate actively in democracy, the employee mutual is controlled by its 
members, providing them with training, childcare and jobseekers' allowances. It aims, above all, to remain in direct contact with employers, selling them the 'services' of its members to whom it offers the best adapted workforce for the jobs proposed.

Although not openly presented as a direct rival of the trade unions, the employee mutual is nevertheless an indication that trade union representation seems to find itself at a dead-end. Built as a counter-model of the 'monolithic' structure (a criticism levelled at the trade unions by Thirdwayers) the employee mutual contains, more importantly, all the paths of reconversion which these same individuals attribute to the trade unions. Weakened by the Conservative governments of the 1980s, the trade unions appear in the literature of the Third Way as the relics of the Fordist era. As a result, they have no alternative but to change (Mandelson and Liddle 1996, 226). The rebirth of mutualism can, therefore, be a solution, coming at an opportune time. Such a reconversion seems all the more logical as the trade unions are the direct heirs of the friendly societies. Weary of the 'ideological' stance adopted by the unions, their members demand, first and foremost, that they move towards the provision of health and insurance services, management of pension funds and counselling.

Such 'suggestions' are not necessarily devoid of all ulterior motives. The future of the trade union movement, outlined by some entrepreneurs of the Third Way, must be placed in the context of the repositioning of the Labour party, begun during the 1980s. By limiting the sphere of activity of the trade unions to a social one, the Third Way has diverted them from political activity which in the past might have been responsible for thwarting the electoral ambitions of the British 'governmental left.' Indeed, in 1984, a year-long National Union of Mineworkers' strike ended in the capitulation of the miners. Hostile to the wave of strikes which led, in the late seventies, to the Winter of Discontent, 'public opinion' was overwhelmingly against this new movement. The rejection of the trade unions by what would seem to be the bulk of voters consequently forced Kinnock's Labour party to distance itself 
from those very people at their origin a century earlier. In 1999, Tony Blair was to make this position 'official' by declaring that the trade unions should not expect to receive 'any favours' but 'fair treatment' from a Labour government.

Interested in a mutualism in harmony with its discourse on community, the Third Way has also revealed its individualistic inclination by turning to a new figure in the framework of the renovation of civil society and the management of welfare: the social entrepreneur.

\section{The social entrepreneur or the ideal local leader}

Embodying the ideal local leader in the field of welfare and epitomising the perfect citizen promoted by the Third Way, the social entrepreneur can be situated at the common borders of the public, private and third sectors, combining their respective values. He is characterised by a 'creative individualism,' nurtured by a sense of what is in the common interest, by an enlightened opportunism and an innovatory mind (Leadbeater 1997a, 11). The social entrepreneur has swiftly become a recurring figure in the imaginary world created by the space of theorisation of the Third Way. A few weeks after his arrival at Downing Street, Tony Blair vowed that his government would support 'the thousands of social entrepreneurs... who bring to social problems the same enterprise and imagination business entrepreneurs bring to wealth creation' (Blair 1997).

Individualistic while fighting for the interests of the community, charismatic, endowed with local expertise, breaker of rules and flouter of stifling conventions, quick to create alliances, the social entrepreneur is presented as the antithesis of the civil servant (Coote 1999, 126). He is an indictment of a Welfare State judged excessively bureaucratic. According to Charles Leadbeater, the autonomy and spirit of initiative which characterise the social entrepreneur signal him out as a natural member of the movement set in motion by 'new individualism' and destine him to become the agent 'of a modern type of welfare for the 
twenty-first century' (Leadbeater 1997b, 8). To fulfil this role, the social entrepreneur must answer local needs left unsatisfied until now by traditional social structures. Indeed, he distinguishes himself thanks to a capacity to mobilise, at the local level, the resources unexploited or underexploited by the State or by any other authority. Leadbeater gives the example of Andrew Mawson, a pastor who, in the 1980s, succeeded in uniting the inhabitants of an underprivileged neighbourhood in east London in a project which consisted in refurbishing dilapidated buildings belonging to the Reformed Church. From abandoned premises there swiftly rose a nursery, a crèche, various art centres and a health centre.

The social entrepreneur is, moreover, at the centre of what Leadbeater describes as the 'virtuous circle of social capital' (Leadbeater 1997b, 67). Inspired by Robert Putnam, the notion of 'social capital' implies shared values, norms of reciprocity, mutual obligations and expectations which characterise social relationships and encourage cooperation between individuals, leading to the birth of a sense of common interest. Since it is mainly built on 'trust,' social capital also dons the democratic mantle by facilitating discussion between individuals. Stronger social ties have an impact on the market and consequently, contribute to economic growth. Social capital thus reconciles opportunely the concerns of the individual and the interests of society. For the new agent of welfare, social capital is the primary weapon in the fight against social exclusion, crime and the different causes of 'community decline.' The capital comes from the various social networks and contacts established by the social entrepreneur to achieve his ends. Gradually, he becomes involved in the setting up of new local services, the rehabilitation of certain public places, etc. These investments, uniting individuals mobilised by the social entrepreneur, will produce dividends by reviving collaboration and social ties at the heart of the community. This new social fabric will, in its turn, encourage the setting up of new community projects and will subsequently bind individuals behind the same shared values. 
Does the distribution of tasks sketched out here mean a simple privatisation of "the Social?' This premise appeals to the left insofar as it transforms British 'new progressivism' into the avatar of neo-Liberalism. The answer to such a question is more complex and less clear-cut. Although this kind of 'governance' transfers part of the State's responsibilities to non-State entities, it is nonetheless clear that the State retains its role as social regulator and has the monopoly on deciding who the new participants should be. It is also the State's role to bestow legitimacy on their new status. The State thus becomes the sole centre of gravity of 'governance of governance.' (Jayasuryia 2004, 490). Its 'partners', whether they be social entrepreneurs, mutualist groups or community leaders are like satellites revolving in its orbit. This can explain Janet Newman's suggestion that, paradoxically, the main consequence of 'privatisation of the Social' is to make it easier for the State to impose its values:

\footnotetext{
The spread of an official and legitimated discourse of partnership has the capacity to draw local stakeholders, from community groups to business organisations, into a more direct relationship with government's agenda. ...From the perspective of the voluntary and community sectors, partnerships may represent 'dangerous liaisons,' implying a process of incorporation into the values of the dominant partner. (Newman 2001, 125-126)
}

Finally, one may add that, in a different context, Vivien Schmidt has shown how the fact that the State delegates some of its functions and duties to other agents does not mean a loss of power or the choice of a policy of 'non-interference.' In fact, such a movement should be read as a shift from 'doing' to 'having done' or 'doing with,' for the State continues to set the targets, to lay down directives and, above, all to demand that its partners be held accountable for the activities delegated to them (Schmidt 2005). 


\section{References}

Blair, T., (1994), quoted in The Guardian, 25 May.

Blair, T. (1997), 'Will to Win', Speech at Aylesbury Estate, 2 June.

Blair, T. (2001), 'The Strong Society - Rights, Responsibilities and Reform', Speech at Newport, 30 May.

Brown, G (1995), 'Foreword', in Crouch, C. and Marquand, D. (eds.), Reinventing Collective Action (Oxford: Blackwell/The Political Quartely).

Brown, G. (2000), Speech at the NCVO Conference, 9 February.

Coote, A. (1999), 'The Helmsman and the Cattle Prod', in Gamble, A. and Wright, T. (eds.), The New Social Democracy. (Oxford: The Political Quarterly/Blackwell).

Crouch, C. (2004), 'The State and Innovations in Economics Governance', in Gamble, A. and Wright, T. (eds.).

Donzelot, J. (1984), L'invention du Social. Essai sur le déclin des passions politiques. (Paris: Fayard). Esping-Andersen, G. (1990), The Three Worlds of Welfare Capitalism. (Cambridge: Polity Press).

Field, F. (1996), Stakeholder Welfare. (London: IEA).

Field, F. (1997), 'The Welfare and the Third Way', Speech at the Victoria and Albert Museum, 24 September.

Foote, G. (1997), The Labour Party's Political Thought. A History. (New York: St Martin's Press).

Gamble, A. (1988), The Free Economy and the Strong State. The Politics of Thatcherism. (Basingtoke: MacMillan).

Gamble, A. and Wright, T. (eds.) (2004), Restating the State. (Oxford: The Political Quarterly Publishing).

Giddens, A. (1998), The Third Way. The Renewal of Social Democracy. (Cambridge: Polity Press).

Hargreaves, I. (1998), 'A Step Beyond Morris Dancing: The Third Sector Revival', in Ian Hargreaves and Ian Christie (eds.), Tomorrow's Politics. The Third Way and Beyond. (London: Demos).

Hargreaves, I. (1999), New Mutualism. In from the Cold. The Co-operative Revival and Social Exclusion. (London: The Co-operative Press).

Jayasuriya, K. (2004), ‘The New Regulatory State and Relational Capacity', Policy \& Politics 32: 4.

Leadbeater, C. (1997a), Civic Spirit. The Big Idea for a new political Area. (London: Demos).

Leadbeater, C. (1997b), The Rise of the Social Entrepreneur. (London:Demos).

Leadbeater, C. and Martin, S. (1999), The Employee Mutual. Combining Flexibility with Security in the new World of Work. (London: Demos).

Mandelson P. and Liddle, R. (1996), The Blair Revolution. Can New Labour Deliver? (London: Faber and Faber).

Merrien, F.-X. et al (eds.) (2005), L'État social. Une perspective internationale. (Paris: Armand Collin). 
Mulgan, G. and Landry, C. (1995), The Other Invisible Hand. Remaking Charity for the $21^{\text {st }}$ Century. (London: Demos).

Newman, J. (2001), Modernising Governance. (London: Sage).

Peters, G. (1993), 'Managing the Hollow State', in Eliassen, H. and Koiman, J. (eds), Managing Public Organizations. (London: Sage).

Pollard, S. et al. (1994), 'Towards a more Co-operative Society: Ideas on the Future of the British Labour Movement and Independent Healthcare', Independent Healthcare 1.

Rose, N. (1999), 'Inventiveness in Politics', Economy and Society 28: 3.

Schmidt, V. (2005), 'L'État, l'économie et la protection sociale aux États-Unis et en Europe', Critique internationale 27.

Shaw, E. (1994), The Labour Party since 1979. Crisis and Transformation. (London: Routledge).

Stoker, G. (2004), 'New Localism, Progressive Politics and Democracy', in Gamble, A. and Wright, T. (eds.).

Thompson, E. P. (1963), The Making of English Working Class. (New York: Vintage Books). 